\title{
EXPERIMENTAL INVESTIGATION ABOUT THE INFLUENCE OF AIRFLOW ON DROPLET SIZES OF MECHANICAL NOZZLES FOR COAL MINING FACE
}

\author{
Gang Zhou, Mao Xu, Han Qiu, Wen Nie, Weimin Cheng, Cong Chen
}

Original scientific paper

High-pressure spraying is one of the primary methods for dust prevention in coal mine fully mechanized caving face, and the atomization effects of mechanical nozzles influence dedusting result significantly. While so far, the nozzles are selected by technician's subjective arbitrariness mainly, affecting improving dedusting effect. For this reason, before and after simulating actual air velocity of coal workface, the comparative experiments on the atomization effects of the six kinds of commonly used mechanical nozzles were conducted with self-designed spraying platform. Based on the test data, the average droplets' size and the atomization quality order of different mechanical nozzles were obtained, moreover, the airflow's turbulence influence on droplets' sizes was induced. Finally, according to the experimental results, nozzles used in external spray of shearer were selected for \#10310 working face of Xinglongzhuang coal mine in China, which had achieved great dust reduction effects.

Keywords: coal mine fully mechanized caving face; dust suppression; different types of mechanical nozzles; engineering application; simulating air velocity; turbulence influence to droplet sizes

\section{Eksperimentalno ispitivanje utjecaja protoka zraka na veličine kapljica mehaničkih mlaznica za iskop ugljena}

Izvorni znanstveni članak

Visokotlačno raspršivanje je jedna od primarnih metoda za sprječavanje prašine u potpuno mehaniziranom iskopu, a učinci raspršivanja mehaničkih mlaznica značajno utječu na učinak raspršivanja. Do sada su mlaznice uglavnom odabirane subjektivnom proizvoljnošću tehničara, utječući na poboljšanje učinka suzbijanja prašine. Iz tog razloga, prije i poslije simulacije stvarne brzine zraka iskopa ugljena, provedeni su usporedni pokusi učinaka atomizacije na šest vrsta najčešće korištenih mehaničkih mlaznica s vlastitom platformom za prskanje. Na osnovu podataka o ispitivanju dobivene su prosječne veličine kapljica i redoslijed kvalitete raspršivanja različitih mehaničkih mlaznica, a osim toga je induciran utjecaj turbulencije protoka zraka na veličine kapljica. Konačno, prema eksperimentalnim rezultatima, mlaznice koje se koriste u vanjskom raspršivaču su odabrane za \#10310 radnih iskopa rudnika ugljena Xinglongzhuang u Kini, koji je postigao velike učinke smanjenja prašine.

Ključne riječi: rudnik ugljena s potpuno mehaniziranim iskopom; suzbijanje prašine; različite vrste mehaničkih mlaznica; inženjerska primjena; simuliranje brzine zraka; utjecaj turbulencije na veličine kapljica

\section{Introduction}

As one of the main hazards produced in coal mine production, coal dust seriously threatens the safe production and miners' physical and mental health. From the beginning of 2000 to the end of 2014, 14 dust explosion accidents happened in China coal mines, which caused 472 deaths [1]. Only in 2014, 12405 pneumoconiosis of China coal mine were reported. More seriously, the annual medical expenses spent on treating pneumoconiosis in China could reach as much as 8 billion RMB [2].

With the popularization of high yield and more efficient production process in a coal mine, the dust concentration at fully mechanized caving face becomes more and more serious. According to the field survey, dust concentration at fully mechanized caving face can reach $2000-3000 \mathrm{mg} / \mathrm{m}^{3}$ without any dust reduction measures [3]. In addition, as one of the main dust producing areas, the dust amount at fully mechanized caving face accounts for more than $60 \%$ of the whole mine, and the probability of workers' getting pneumoconiosis in this type of workface is as high as $65 \%$ [4]. Therefore, research on dust control technology at fully mechanized caving face is of great significance to the safe production and occupational health. Nowadays, the main dust control measures taken at fully mechanized caving face include coal seam water injection, spraying, ejecting scrubber, ventilation and enclosed dust control, among which spraying is still the most common dust reduction method applied in coal face. Therefore, some scholars have researched spraying theory and experiment for many years. As early as 1976, American scholars Brown and Wengerde proposed the mechanism of "micro-fine water mist capturing dust" [5,6]. Russian expert Димакин concluded an empirical formula for spray dedusting of one mechanical nozzle [7]. Faeth studied the atomization angle and flowrate of nozzles under different air and liquid pressure, based on which a new type of nozzle was designed [8]. In China, Ma, S. P. and Kou Z. M. studied spray dedusting mechanism, and established relations between water pressure and dedusting efficiency, finally the dust reduction efficiency and the spraying parameters were matched $[9 \div 11]$. Quan, Y. Y. studied the structural principle of spiral-type nozzle and investigated the actual underground conditions, and finally determined that when water pressure was $2.5 \mathrm{MPa}$, nozzle with orifice diameter of $1 \mathrm{~mm}$ could obtain the best dust reduction effects [12]. Cheng, W. M. conducted measurement analysis of droplet sizes on the same type nozzle with 5 different orifices under 5 different spraying pressures, then achieving the best water pressure [13]. Zeng, Z. X. proposed ways for promoting nozzle's atomization effect according to atomization mechanism and experiments, the ways included increasing the relative speed difference between air and liquid, improving the outlet velocity of liquid phase [14]. Nie, W. simulated and analyzed the droplet's particle size and velocity distribution of direct-jet nozzles by CFD software [15]. $\mathrm{Li}, \mathrm{X}$. H. built a mathematical model of single droplet capturing dust and developed reverse-wind high pressure 
dust remover [16]. Gong, J. S. and Fu, W. Z. analyzed all kinds of air-blast nozzles and their atomization mechanisms, and designed a new type of rotary air-liquid atomizing nozzle, then studied the flow coefficient's influence on atomization effect [17]. Zhao, Y. and Cui, W. $\mathrm{X}$. designed a spray device mixing high pressure airflow with water flow to optimize atomization effects [18]. Although the relevant scholars have carried out extensive researches in theory, experiment and technology of spray dedusting, and the average dust reduction rate can reach nearly $60 \%$ at coal workface after taking the spraying measures. However, the concentrations of whole and respirable dust in miners' main working areas in fully mechanized caving face can still reach above $500 \mathrm{mg} / \mathrm{m}^{3}$ and $260 \mathrm{mg} / \mathrm{m}^{3}$ respectively, namely the dust concentration is still very high.

Through field research at fully mechanized caving face, it can be known that the following three reasons mainly contribute to the high dust concentration: (1) High pressure mechanical nozzles have many categories with different atomization effects, and experimental researches on atomization effects of different type nozzles are not enough. (2) Spray dedusting effects are influenced by the relative movement between airflow and droplets, while the air velocity's influence on droplet has not been considered when measuring droplet size. (3) Technicians on the production site select spray nozzles by their subjective experience, leading a low efficiency dust reduction. Therefore, in view of the above three problems, the droplet size measurement of the six kinds of commonly used mechanical nozzles before and after ventilation were conducted through spraying experiment platform which can simulate the actual air velocity of fully mechanized caving face. Then the atomization effects of different types of nozzles and airflow turbulence's influence on droplet size were achieved. Finally, experimental results were applied into the field practice, and the theory of mechanical nozzle atomization and spraying dedusting were enriched.

\section{Brief introduction to simulation experiment platform of mechanical nozzle atomization}

The experiment platform mainly consists of enclosed cabinet and fan. The schematic diagram of the platform is shown in Fig. 1.

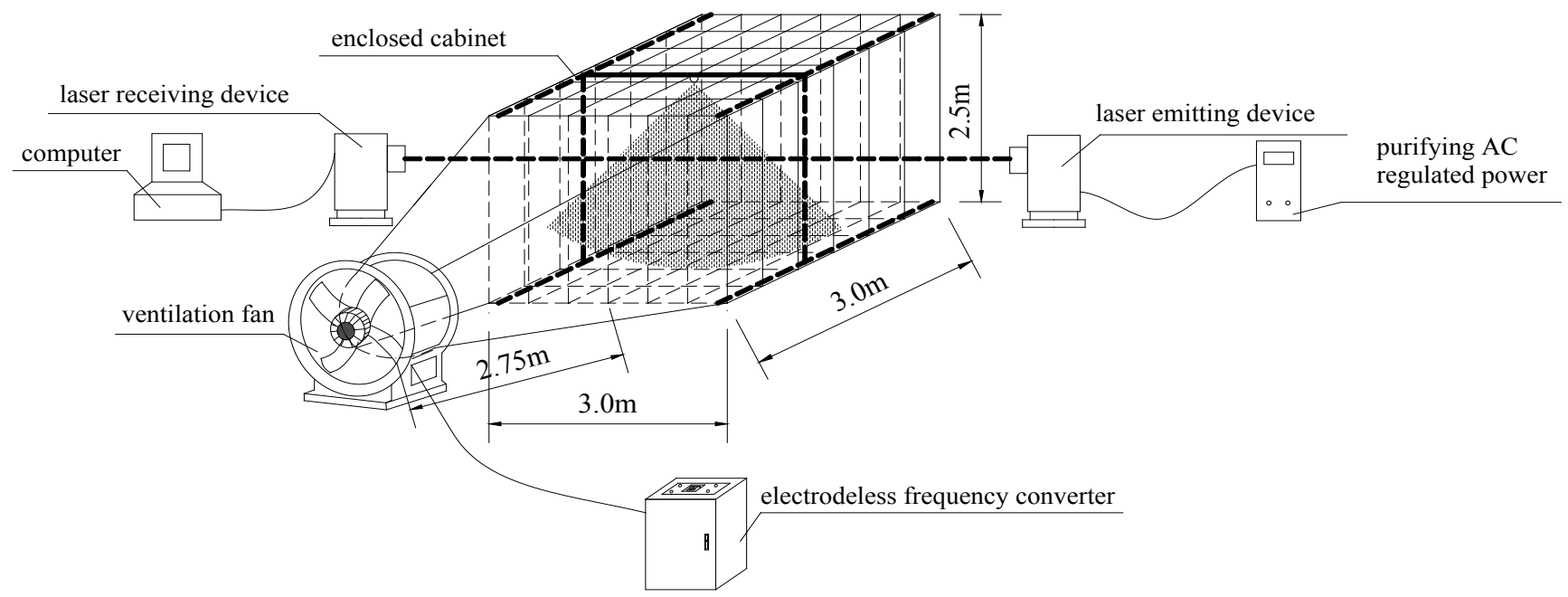

Figure 1 Schematic diagram of spraying simulation experiment platform

Enclosed cabinet mainly consists of two parts, namely gradually expanded section with shape of quadrangular prismaid for inlet air, and cuboid section with length, width and height of $3.0 \mathrm{~m}, 3.0 \mathrm{~m}$ and $2.5 \mathrm{~m}$ respectively. The length and gradually expanded angle of the former part is $2.75 \mathrm{~m}$ and $22.6^{\circ}$. The cross-section of air inlet was a circle with diameter of $1.4 \mathrm{~m}$, and that of air outlet was rectangle, and the section was $3.0 \times 2.5 \mathrm{~m}$. The connection line between laser emitting device and receiving device was perpendicular to the direction of airflow.

The \#FZ40/35-11/12(s) axial flow fan (diameter: $1.4 \mathrm{~m}$, speed: $750 \mathrm{r} / \mathrm{min}$, blade angles: $14^{\circ}$, number of blades: 10) was selected. The fan was equipped with a \#S018R5G3 electrodeless frequency converter (power: $18.5 \mathrm{~kW}$ ) and an electric cabinet. Adjusting of airflow velocity in this experiment platform was conducted by electrodeless frequency converter.

\section{Description of experimental methods}

\subsection{Mechanical nozzles used in the atomization test}

Currently, the common used mechanical nozzle in engineering field is various, which can be mainly divided into pressure nozzle, rotating nozzle, air-blast nozzle, effervescent nozzle, electrostatic nozzle and vibration nozzle. Among them, due to the advantages of good atomization performance, relatively cheap, easy to use and so on, pressure nozzle has been widely applied in the coal mine. Furthermore, the pressure nozzle is mainly divided into direct-spray type, single centrifugal nozzle and mixed centrifugal nozzle. On the basis of a large number of investigation and research on dust-suppression spray nozzles, a more detailed classification of pressure nozzle into six types has been done for the first time in this paper according to the differences of material, internal mechanical structure, atomization type and orifice diameter. Then an optimization selection of typical nozzle for each type is made to prepare for the 
atomization experiment. Therefore, these six kinds of mechanical nozzle selected in this article represent the common used nozzle types at present in coal mines, and the experimental results are of good universality and versatility.

The physical maps of the six selected mechanical nozzles are shown in Fig. 2, and the detailed classifications for these nozzles are shown in Tab. 1.
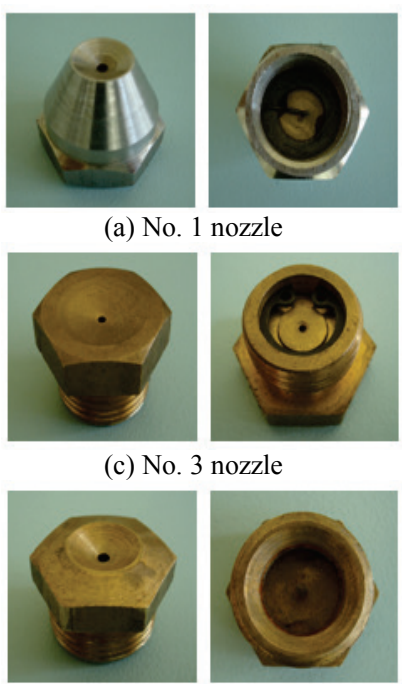

(a) No. 1 nozzle

(c) No. 3 nozzle

(f) No. 5 nozzle
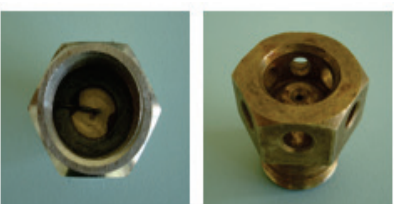

(b) No. 2 nozzle

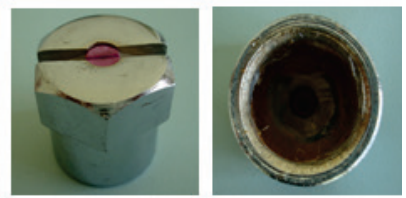

(d) No. 4 nozzle

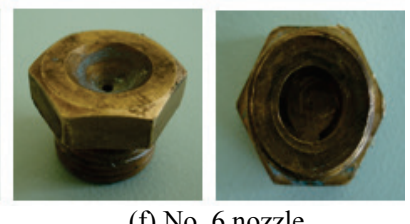

(f) No. 6 nozzle

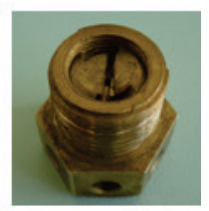

Figure 2 Physical map of mechanical nozzles used in the atomization

\begin{tabular}{|c|c|c|c|c|}
\hline $\begin{array}{l}\text { Nozzle } \\
\text { number }\end{array}$ & Material & $\begin{array}{c}\text { Orifice } \\
\text { diameter } / \mathrm{mm}\end{array}$ & $\begin{array}{c}\text { Atomization } \\
\text { type }\end{array}$ & $\begin{array}{l}\text { Mist flow } \\
\text { shape }\end{array}$ \\
\hline No. 1 & $\begin{array}{c}\text { Stainless } \\
\text { steel }\end{array}$ & 2.0 & $\begin{array}{c}\text { Vortex } \\
\text { centrifugal } \\
\text { type (with } \\
\text { gradually } \\
\text { reduced } \\
\text { body) }\end{array}$ & Full cone \\
\hline No. 2 & Copper & 1.5 & $\begin{array}{l}\text { Tangential } \\
\text { centrifugal } \\
\text { mixed type }\end{array}$ & Beam shape \\
\hline No. 3 & Copper & 1.8 & $\begin{array}{c}\text { Vortex } \\
\text { centrifugal } \\
\text { mixed type }\end{array}$ & Full cone \\
\hline No. 4 & Ceramic & 2.5 & $\begin{array}{c}\text { Direct-spray } \\
\text { type }\end{array}$ & Fan shape \\
\hline No. 5 & Copper & 2.0 & $\begin{array}{l}\text { Vortex } \\
\text { centrifugal } \\
\text { type } \\
\text { (without } \\
\text { gradually } \\
\text { reduced } \\
\text { body) }\end{array}$ & Full cone \\
\hline No. 6 & Copper & 1.3 & $\begin{array}{c}\text { Tangential } \\
\text { centrifugal } \\
\text { type }\end{array}$ & $\begin{array}{c}\text { Umbelliform } \\
\text { (hollow } \\
\text { cone) }\end{array}$ \\
\hline
\end{tabular}

\subsection{Experiment procedure}

(1) Starting the spraying water system without turning on the fan, the nozzles' spatial locations were changed one by one, and particle sizes of droplets at different locations were measured by \#Winner313 laser particle size analyzer respectively. As shown in Fig. 3, particle sizes of mechanical nozzles in the following 9 locations were tested in this experiment: $1 \#-(1250,0)$,
2\#-(1250, -500), 3\#-(1250, 500), 4\#-(789, 0), 5\#-(789, $-500), 6 \#-(789,500), 7 \#-(328,0), 8 \#-(328,-500)$ and 9\#-(328, 500).

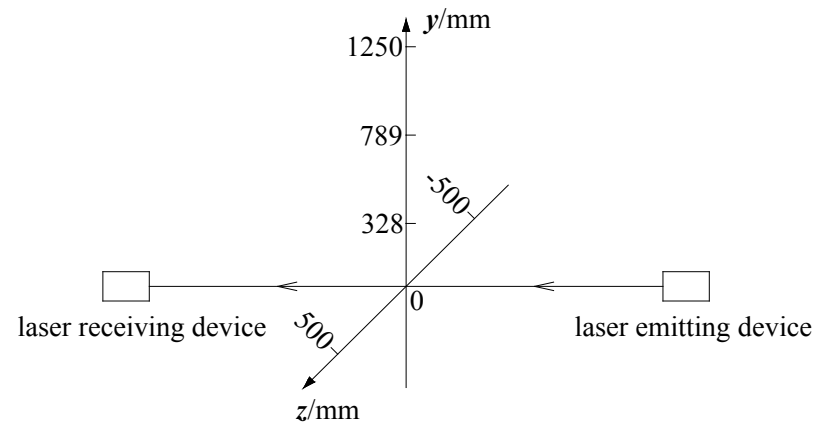

Figure 3 Diagram of nozzles' locations

(2) The variation of the mean diameter and characteristic diameter of droplets along axial and radial direction of the spray field are analyzed systematically when the mechanical nozzle at different positions, and relative variation laws will be obtained. Among them, Sauter mean diameter (SMD) and volume-weighted average diameter are chosen as mean diameter indexes. Representative diameters refer to the several feature points in the particle diameter cumulative distribution curve that the number of droplets whose diameters are less than feature point's diameter accounts for the percentage of all the number of droplets.

(3) The atomization quality order of different mechanical nozzles can be obtained by the analysis of atomization performance of each nozzle.

(4) Starting fan, its rotating speed was adjusted to $400 \mathrm{r} / \mathrm{min}$, and the corresponding airflow velocity was $1.5 \mathrm{~m} / \mathrm{s}$ (similar to the usual velocity in fully mechanized caving face in China). Then the nozzles' spatial locations were also changed one by one, and the distribution of particle sizes under airflow could be analyzed.

(5) The variation laws of droplets diameter along the axial and radial direction of spray filed before and after turning on the fan is comparatively analyzed. The effect of air flow on the mean diameter of droplets in the whole spray field is analyzed generally.

It should be mentioned that based on the analysis of the relationship between spray water pressure and dust reduction effect at fully mechanized caving face, it could be known that the larger the water pressure is, the smaller the particle size of droplet will be, and $8.0 \mathrm{MPa}$ is the best water supply pressure $[19,20]$. Therefore, spray water pressure in this experiment was unified as 8.0 $\mathrm{MPa}$.

\section{Results and discussions}

4.1 Particle size measurement of droplet field without airflow

The frequency distribution and cumulative distribution of different measurement position of each mechanical nozzle could be obtained by the analysis software applied to the laser analyzer, for instance, in the $(1250,0)$ position of No. 1 nozzle, the distribution is shown as Fig. 4. 


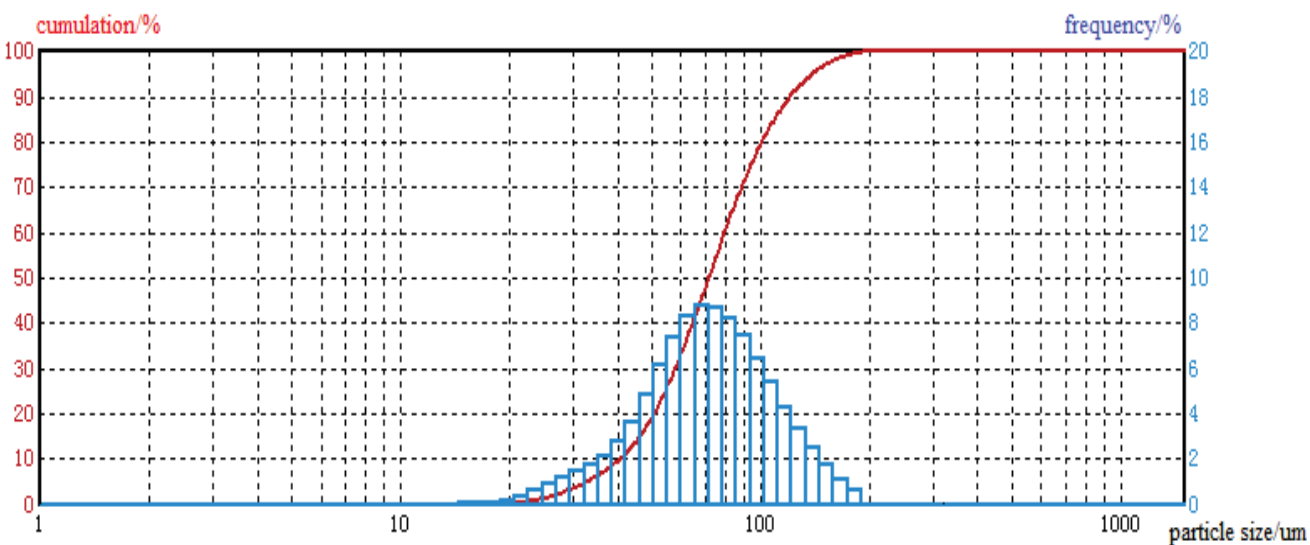

Figure 4 Frequency and cumulative distribution in the $(1250,0)$ position of No. 1 nozzle

Table 2 The droplet size distribution of each mechanical nozzle without starting fan

(a) No. 1 nozzle

\begin{tabular}{|c|c|c|c|c|c|}
\hline Nozzle position & D10 & D50 & D90 & D [3, 2] & D [4, 3] \\
\hline $1 \#$ & 41.567 & 71.449 & 126.646 & 63.957 & 76.456 \\
\hline $2 \#$ & 20.988 & 69.396 & 96.242 & 61.061 & 69.192 \\
\hline $3 \#$ & 40.404 & 52.736 & 83.372 & 39.71 & 52.573 \\
\hline $4 \#$ & 40.727 & 78.2 & 101.365 & 67.878 & 71.326 \\
\hline $5 \#$ & 20.28 & 42.247 & 68.426 & 35.441 & 43.791 \\
\hline $6 \#$ & 32.798 & 62.037 & 99.885 & 54.287 & 65.132 \\
\hline $7 \#$ & 38.13 & 54.661 & 66.195 & 51.655 & 56.743 \\
\hline $8 \#$ & 21.753 & 42.794 & 68.013 & 40.165 & 44.509 \\
\hline 9\# & 27.571 & 42.006 & 77.858 & 36.834 & 44.817 \\
\hline \multicolumn{7}{|c|}{ (b) No. 2 nozzle } \\
\hline
\end{tabular}

\begin{tabular}{|c|c|c|c|c|c|}
\hline Nozzle position & $\mathrm{D} 10$ & $\mathrm{D} 50$ & $\mathrm{D} 90$ & $\mathrm{D}[3,2]$ & $\mathrm{D}[4,3]$ \\
\hline $1 \#$ & 55.558 & 100.78 & 157.147 & 88.335 & 103.773 \\
\hline $2 \#$ & 38.124 & 66.51 & 121.7 & 58.838 & 72.932 \\
\hline $3 \#$ & 34.792 & 55.982 & 81.673 & 52.988 & 58.48 \\
\hline $4 \#$ & 48.588 & 94.011 & 164.28 & 81.121 & 98.132 \\
\hline $5 \#$ & 39.158 & 68.444 & 113.122 & 59.813 & 72.207 \\
\hline $6 \#$ & 35.847 & 59.389 & 77.478 & 54.161 & 58.807 \\
\hline $7 \#$ & 48.119 & 80.724 & 112.276 & 70.878 & 80.52 \\
\hline $8 \#$ & 36.676 & 53.318 & 79.395 & 50.485 & 55.089 \\
\hline $9 \#$ & 33.028 & 56.425 & 75.897 & 49.207 & 56.38 \\
\hline
\end{tabular}

(e) No. 5 nozzle

\begin{tabular}{|c|c|c|c|c|c|}
\hline Nozzle position & $\mathrm{D} 10$ & $\mathrm{D} 50$ & $\mathrm{D} 90$ & $\mathrm{D}[3,2]$ & $\mathrm{D}[4,3]$ \\
\hline $1 \#$ & 56.181 & 93.59 & 143.83 & 83.004 & 95.809 \\
\hline $2 \#$ & 26.168 & 56.835 & 99.224 & 46.384 & 60.567 \\
\hline $3 \#$ & 34.793 & 78.616 & 139.416 & 62.912 & 83.766 \\
\hline $4 \#$ & 46.472 & 85.592 & 132.908 & 73.78 & 88.122 \\
\hline $5 \#$ & 27.902 & 57.577 & 91.505 & 46.142 & 58.95 \\
\hline $6 \#$ & 25.93 & 51.414 & 81.679 & 43.569 & 52.865 \\
\hline $7 \#$ & 28.221 & 50.614 & 126.513 & 45.75 & 75.158 \\
\hline $8 \#$ & 25.148 & 52.922 & 84.651 & 47.025 & 54.581 \\
\hline $9 \#$ & 25.579 & 43.418 & 75.567 & 39.934 & 47.847 \\
\hline
\end{tabular}

Without starting fan, the particle size distribution of droplets formed by each nozzle at different spatial positions is shown in Tab. 2 and Fig. 5.

The meanings of each atomization index in Fig. 5 were:

D10: particle size of droplet with cumulative distribution of $10 \%$, namely the quantity of droplets whose particle size less than this index accounts for $10 \%$ of all droplets. D50 and D90 have similar meanings with D10.

$$
\mathrm{D}[3,2]=X_{S V}=\frac{\sum N_{i} \cdot d_{i}^{3}}{\sum N_{i} \cdot d_{i}^{2}} \text {, representing Sauter mean }
$$

diameter $(\mathrm{SMD}) ; \mathrm{D}[4,3]=X_{P V}=\frac{\sum N_{i} \cdot d_{i}^{4}}{\sum N_{i} \cdot d_{i}^{3}}$, representing volume-weighted average diameter where $d$ is the equivalent diameter of circumference, and $d=C / \pi$,

\begin{tabular}{|c|c|c|c|c|c|}
\hline \multicolumn{6}{|c|}{ (c) No. 3 nozzle } \\
\hline Nozzle position & D10 & D50 & D90 & $\mathrm{D}[3,2]$ & $\mathrm{D}[4,3]$ \\
\hline $1 \#$ & 42.582 & 96.567 & 152.793 & 79.313 & \begin{tabular}{|l|l|}
98.109 \\
\end{tabular} \\
\hline $2 \#$ & 30.502 & 46.773 & 73.343 & 44.17 & 49.83 \\
\hline $3 \#$ & 24.536 & 37.41 & 67.027 & 32.366 & 40.804 \\
\hline $4 \#$ & 46.41 & 84.791 & 135.522 & 71.455 & 87.546 \\
\hline $5 \#$ & 30.426 & 46.749 & 74.232 & 44.352 & 50.078 \\
\hline $6 \#$ & 18.631 & 42.575 & 67.117 & 38.361 & 44.854 \\
\hline $7 \#$ & 31.709 & 59.686 & 87.684 & 52.085 & 60.327 \\
\hline $8 \#$ & 19.97 & 40.796 & 67.162 & 34.636 & 42.585 \\
\hline 9\# & 18.796 & 38.689 & 70.884 & 33.093 & 42.443 \\
\hline \multicolumn{6}{|c|}{ (d) No. 4 nozzle } \\
\hline Nozzle position & D10 & D50 & D90 & $\mathrm{D}[3,2]$ & $\mathrm{D}[4,3]$ \\
\hline $1 \#$ & 52.642 & 93.335 & 145.444 & 82.237 & 96.31 \\
\hline $2 \#$ & 42.955 & 79.694 & 125.625 & 69.69 & 82.53 \\
\hline $3 \#$ & 27.708 & 56.192 & 92.034 & 47.657 & 59.292 \\
\hline $4 \#$ & 39.232 & \begin{tabular}{l|l}
2 & 78.056
\end{tabular} & 125.229 & 65.777 & 80.534 \\
\hline 5\# & 37.321 & 68.967 & 113.858 & 61.094 & 73.121 \\
\hline $6 \#$ & 23.291 & 54.559 & 91.332 & 43.598 & 57.098 \\
\hline 7\# & 29.657 & \begin{tabular}{l|l}
7 & 52.645 \\
\end{tabular} & 143.206 & 47.312 & 71.486 \\
\hline $8 \#$ & 19.385 & \begin{tabular}{|l|l|}
5 & 51.987
\end{tabular} & 81.419 & 40.888 & 54.825 \\
\hline 9\# & 24.22 & 50.922 & 83.364 & 42.818 & 53.308 \\
\hline \multicolumn{6}{|c|}{ (f) No. 6 nozzle } \\
\hline Nozzle position & D10 & D50 & D90 & $\mathrm{D}[3,2]$ & $\mathrm{D}[4,3]$ \\
\hline $1 \#$ & 65.117 & 136.952 & 173.273 & 89.042 & 116.905 \\
\hline 2\# & 24.399 & 60.18 & 100.836 & 63.803 & 62.49 \\
\hline $3 \#$ & 26.906 & 91.537 & 136.06 & 46.332 & 96.418 \\
\hline $4 \#$ & 62.706 & 118.594 & 164.563 & 91.658 & 115.247 \\
\hline 5\# & 15.852 & 27.941 & 53.113 & 25.542 & 31.787 \\
\hline $6 \#$ & 29.964 & 69.934 & 113.167 & 55.237 & 71.689 \\
\hline $7 \#$ & 38.041 & 80.451 & 131.454 & 65.267 & 83.119 \\
\hline $8 \#$ & 17.004 & 28.505 & 44.939 & 26.088 & 30.234 \\
\hline 9\# & 16.438 & 35.069 & 61.479 & 28.792 & 37.385 \\
\hline
\end{tabular}

where, $C$ is the section perimeter of droplet, $d_{i}$ is the different particle size of droplet, and $N_{i}$ is the number of droplets with particle size of $d_{i}$.

It could be known by analyzing the test data under the condition without starting fan:

(1) The quality order of nozzles' atomization effects was: No. 3 nozzle ( $\overline{\mathrm{D}} 50=54.893 \mu \mathrm{m}, \overline{\mathrm{D}}[3,2]=47.759$ $\mu \mathrm{m})>$ No. 1 nozzle $(\overline{\mathrm{D}} 50=57.281 \mu \mathrm{m}, \overline{\mathrm{D}}[3,2]=50.110$ $\mu \mathrm{m})>$ No. 5 nozzle $(\overline{\mathrm{D}} 50=63.398 \mu \mathrm{m}, \overline{\mathrm{D}}[3,2]=54.278$ $\mu \mathrm{m})>$ No. 6 nozzle $(\overline{\mathrm{D}} 50=72.129 \mu \mathrm{m}, \overline{\mathrm{D}}[3,2]=54.640$ $\mu \mathrm{m})>$ No. 4 nozzle $(\overline{\mathrm{D}} 50=73.090 \mu \mathrm{m}, \overline{\mathrm{D}}[3,2]=62.734$ $\mu \mathrm{m})>$ No. 2 nozzle $(\overline{\mathrm{D}} 50=75.491 \mu \mathrm{m}, \overline{\mathrm{D}}[3,2]=64.355$ $\mu \mathrm{m})$. Namely, for mechanical atomization nozzles which are commonly used in coal mine with different internal structures, the atomization quality sequence was: vortex centrifugal mixed type $>$ vortex centrifugal type (with 
gradually reduced body) $>$ vortex centrifugal type (without gradually reduced body) $>$ tangential centrifugal type $>$ Direct-spray type $>$ tangential centrifugal mixed type.

(2) In the zone of diffusion angle of atomization field, on the connection line between the centre of nozzle's orifice and any point in the effective jetting range, the closer to the nozzle the droplet is, the smaller its size will be, and vice versa. For example, D10, D50, D90, D[3, 2] and $\mathrm{D}[4,3]$ of droplets formed by No.5 nozzle at different spatial positions $(y, 500)(y=1250,789,328)$ decreased from $34.793 \mu \mathrm{m}$ to $25.930 \mu \mathrm{m}, 25.579 \mu \mathrm{m}$; from $78.616 \mu \mathrm{m}$ to $51.414 \mu \mathrm{m}, 43.418 \mu \mathrm{m}$; from

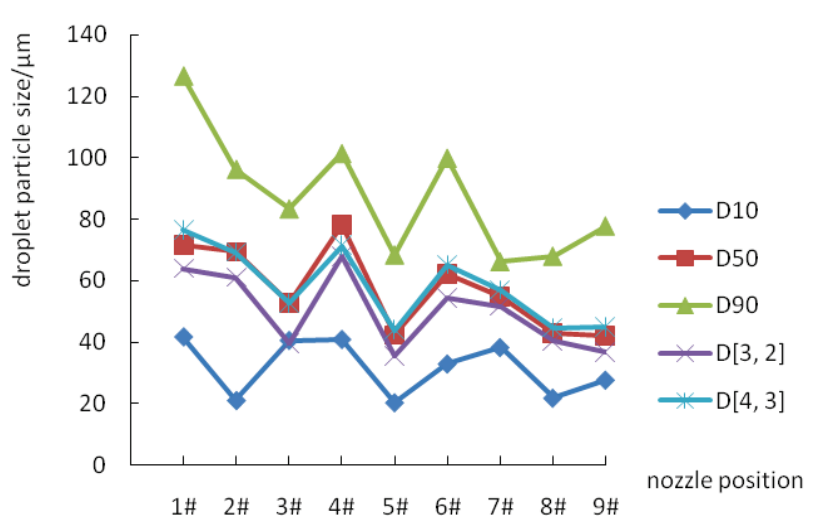

(a) No. 1 nozzle

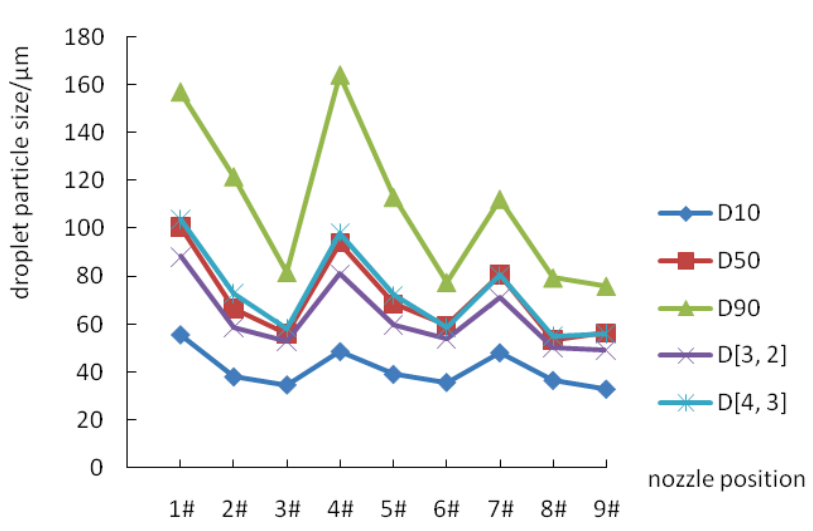

(b) No. 2 nozzle

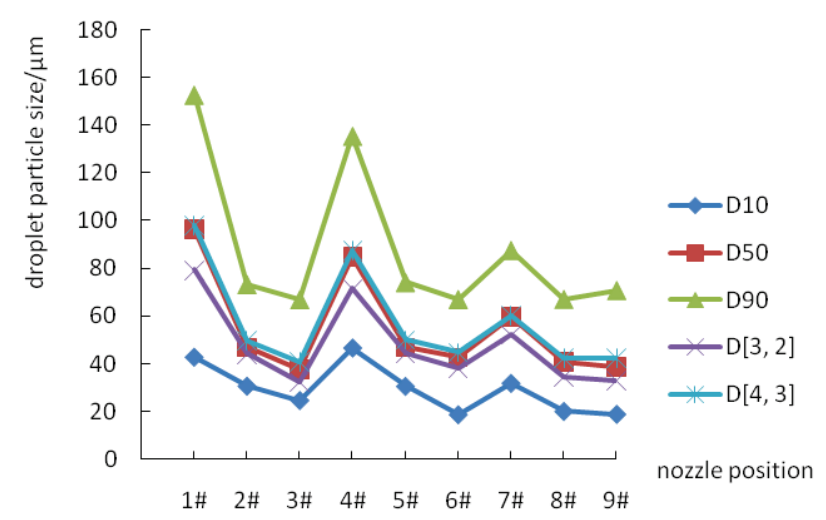

$139.416 \mu \mathrm{m}$ to $81.679 \mu \mathrm{m}, 75.567 \mu \mathrm{m}$; from $62.912 \mu \mathrm{m}$ to $43.569 \mu \mathrm{m}, 39.934 \mu \mathrm{m}$; from $83.766 \mu \mathrm{m}$ to $52.865 \mu \mathrm{m}$, $47.847 \mu \mathrm{m}$ respectively.

(3) On the horizontal plane which was perpendicular to the mist flow's penetration, the closer to the central axis of mist flow the droplet is, the larger its size will be, and vice versa. For example, D10, D50, D90, D[3, 2] and $\mathrm{D}[4,3]$ of droplets formed by No.5 nozzle at different spatial positions $(789, z)(z=0,-500,500)$ decreased from $46.472 \mu \mathrm{m}$ to $27.902 \mu \mathrm{m}, 25.930 \mu \mathrm{m}$; from $85.592 \mu \mathrm{m}$ to $57.577 \mu \mathrm{m}, 51.414 \mu \mathrm{m}$; from $132.908 \mu \mathrm{m}$ to $91.505 \mu \mathrm{m}$, $81.679 \mu \mathrm{m}$; from $73.780 \mu \mathrm{m}$ to $46.142 \mu \mathrm{m}, 43.569 \mu \mathrm{m}$; from $88.122 \mu \mathrm{m}$ to $58.950 \mu \mathrm{m}, 52.865 \mu \mathrm{m}$ respectively.

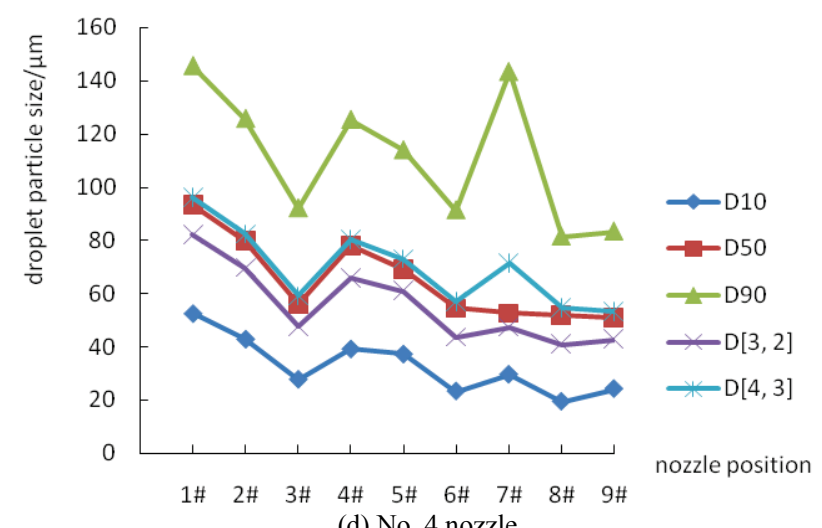
(d) No. 4 nozzle

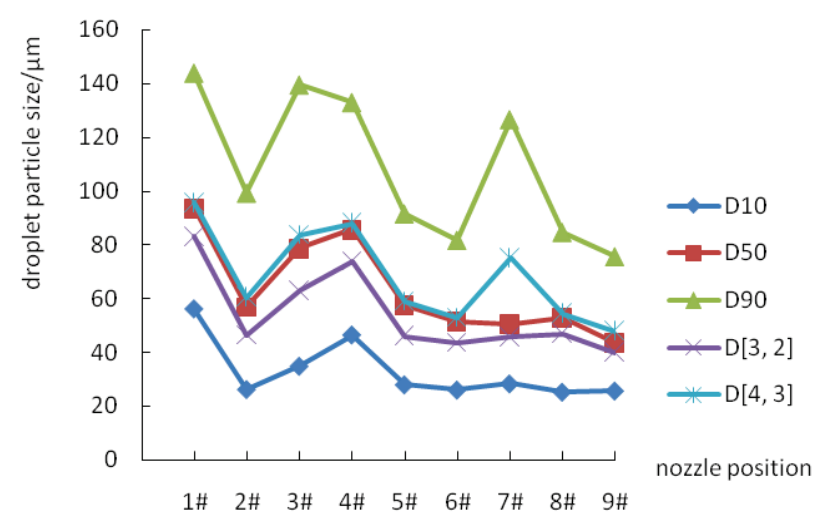

(e) No. 5 nozzle

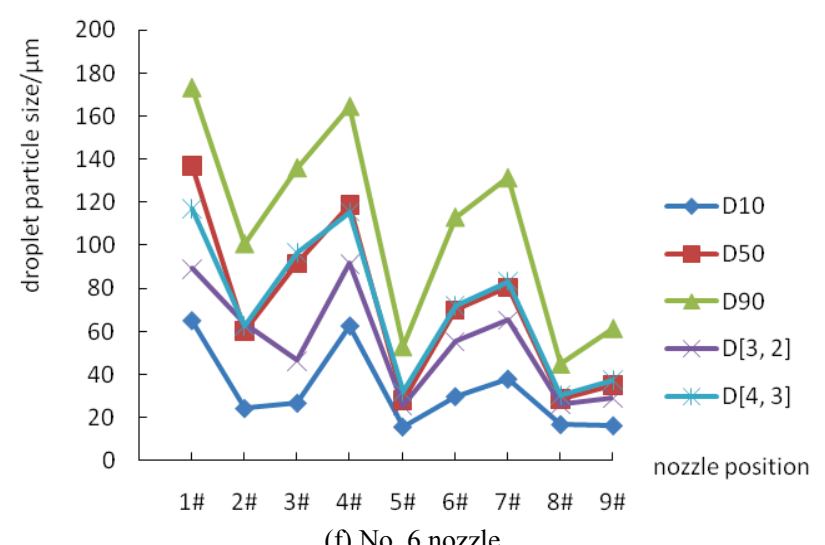

(f) No. 6 nozzle

(c) No. 3 nozzle

Figure 5 Particle sizes of droplets without starting fan 


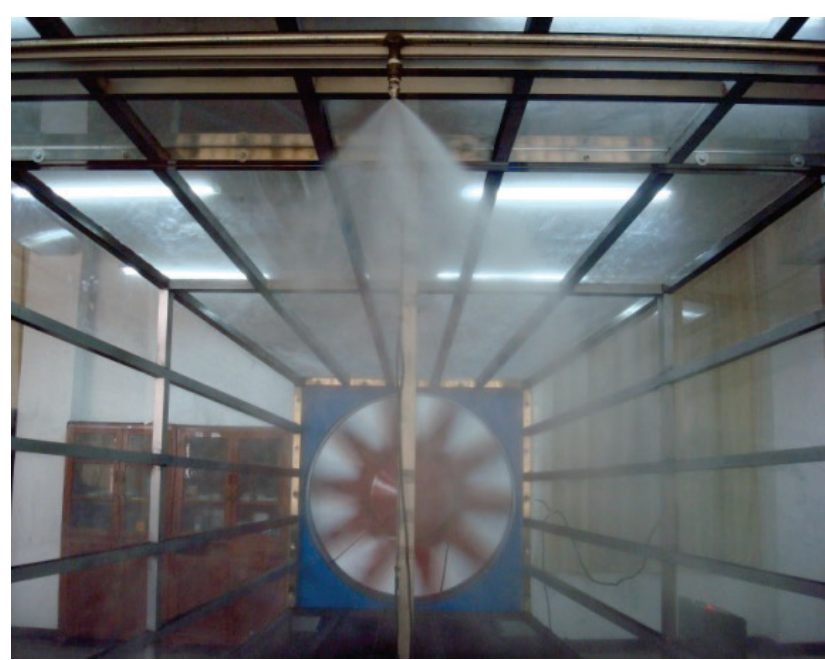

(a) front view

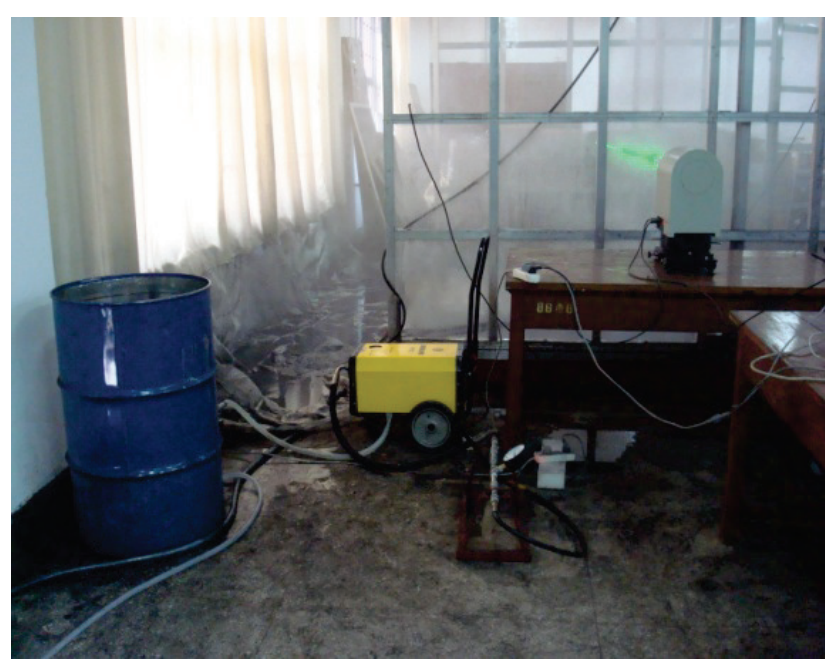

(b) lateral view

Figure 6 The physical map of atomization field formed by No. 1 nozzle under $8.0 \mathrm{MPa}$ water pressure

\subsection{Particle size measurement of droplet field with airflow}

With airflow, the physical map of atomization field formed by No. 1 nozzle under $8.0 \mathrm{MPa}$ water pressure is shown in Fig. 6.

When starting fan, the particle size distribution of droplets formed by each mechanical nozzle at different positions is shown in Tab. 3 and Fig. 7.

It could be known by analyzing the test data under the condition with starting fan:

(1) Similar with that of without airflow, for the atomization fields formed by different mechanical nozzles at different locations, on the connection line between the centre of nozzle orifice and any point in effective jetting range of mist flow, the closer to the nozzle the droplet is, the smaller its size will be, and vice versa.

Table 3 The droplet size distribution of each mechanical nozzle after starting fan (a) No. 1 nozzle

\begin{tabular}{|c|c|c|c|c|c|}
\hline $\begin{array}{c}\text { Nozzle } \\
\text { position }\end{array}$ & $\mathrm{D} 10$ & $\mathrm{D} 50$ & $\mathrm{D} 90$ & $\mathrm{D}[3,2]$ & $\mathrm{D}[4,3]$ \\
\hline $1 \#$ & 29.699 & 56.712 & 91.814 & 48.735 & 59.536 \\
\hline $2 \#$ & 46.013 & 85.12 & 145.661 & 75.373 & 90.695 \\
\hline $3 \#$ & 42.557 & 81.164 & 141.727 & 70.673 & 86.772 \\
\hline $4 \#$ & 27.494 & 58 & 91.803 & 46.895 & 58.71 \\
\hline $5 \#$ & 41.517 & 106.646 & 165.86 & 67.5 & 80.793 \\
\hline $6 \#$ & 35.332 & 53.234 & 96.547 & 56.182 & 67.53 \\
\hline $7 \#$ & 26.573 & 54.36 & 94.113 & 45.592 & 57.142 \\
\hline $8 \#$ & 33.554 & 75.637 & 128.896 & 66.337 & 99.37 \\
\hline $9 \#$ & 31.595 & 64.727 & 102.599 & 51.909 & 61.959 \\
\hline
\end{tabular}

(b) No. 2 nozzle

\begin{tabular}{|c|c|c|c|c|c|}
\hline $\begin{array}{c}\text { Nozzle } \\
\text { position }\end{array}$ & D10 & D50 & D90 & D [3, 2] & $\mathrm{D}[4,3]$ \\
\hline $1 \#$ & 31.664 & 50.649 & 77.453 & 46.731 & 53.047 \\
\hline $2 \#$ & 47.177 & 84.271 & 128.894 & 74.544 & 86.76 \\
\hline $3 \#$ & 59.312 & 119.768 & 166.266 & 97.354 & 116.033 \\
\hline $4 \#$ & 37.787 & 54.03 & 88.112 & 55.399 & 60.962 \\
\hline $5 \#$ & 40.051 & 124.67 & 168.949 & 89.335 & 114.185 \\
\hline $6 \#$ & 44.674 & 55.942 & 94.98 & 53.683 & 61.13 \\
\hline $7 \#$ & 37.395 & 48.512 & 57.7 & 46.235 & 47.835 \\
\hline $8 \#$ & 37.132 & 70.107 & 105.018 & 65.947 & 73.272 \\
\hline $9 \#$ & 44.922 & 49.861 & 75.674 & 49.964 & 54.343 \\
\hline
\end{tabular}

(c) No. 3 nozzle

\begin{tabular}{|c|c|c|c|c|c|}
\hline $\begin{array}{c}\text { Nozzle } \\
\text { position }\end{array}$ & D10 & D50 & D90 & D [3, 2] & $\mathrm{D}[4,3]$ \\
\hline $1 \#$ & 32.18 & 81.729 & 134.838 & 58.468 & 84.377 \\
\hline $2 \#$ & 43.839 & 91.312 & 153.985 & 76.711 & 92.485 \\
\hline $3 \#$ & 37.572 & 95.827 & 152.13 & 66.598 & 97.188 \\
\hline $4 \#$ & 37.579 & 63.487 & 103.283 & 57.89 & 67.785 \\
\hline $5 \#$ & 41.297 & 74.543 & 131.316 & 67.139 & 80.618 \\
\hline $6 \#$ & 38.072 & 71.175 & 125.448 & 63.066 & 76.811 \\
\hline $7 \#$ & 34.746 & 62.796 & 96.253 & 56.039 & 65.005 \\
\hline $8 \#$ & 38.183 & 61.438 & 99.797 & 56.848 & 66.018 \\
\hline $9 \#$ & 43.658 & 69.728 & 108.277 & 65.032 & 73.574 \\
\hline
\end{tabular}

(d) No. 4 nozzle

\begin{tabular}{|c|c|c|c|c|c|}
\hline $\begin{array}{c}\text { Nozzle } \\
\text { position }\end{array}$ & D10 & D50 & D90 & $\mathrm{D}[3,2]$ & $\mathrm{D}[4,3]$ \\
\hline $1 \#$ & 32.659 & 69.093 & 111.524 & 54.525 & 71.006 \\
\hline $2 \#$ & 47.695 & 93.178 & 150.075 & 78.901 & 96.065 \\
\hline $3 \#$ & 51.419 & 102.542 & 157.72 & 85.071 & 103.411 \\
\hline $4 \#$ & 28.053 & 51.333 & 109.064 & 43.512 & 51.679 \\
\hline $5 \#$ & 35.588 & 73.155 & 152.566 & 62.062 & 78.6 \\
\hline $6 \#$ & 48.084 & 93.332 & 145.166 & 79.732 & 96.456 \\
\hline $7 \#$ & 22.107 & 64.169 & 95.501 & 51.373 & 69.648 \\
\hline $8 \#$ & 28.195 & 65.041 & 131.524 & 53.777 & 78.767 \\
\hline $9 \#$ & 30.635 & 67.576 & 150.298 & 55.656 & 73.601 \\
\hline
\end{tabular}

(e) No. 5 nozzle

\begin{tabular}{|c|c|c|c|c|c|}
\hline $\begin{array}{c}\text { Nozzle } \\
\text { position }\end{array}$ & D10 & D50 & D90 & D [3, 2] & $\mathrm{D}[4,3]$ \\
\hline $1 \#$ & 36.34 & 74.959 & 127.235 & 63.383 & 78.894 \\
\hline $2 \#$ & 37.599 & 75.802 & 153.547 & 65.41 & 86.97 \\
\hline $3 \#$ & 45.743 & 87.275 & 142.562 & 75.493 & 90.975 \\
\hline $4 \#$ & 22.329 & 40.988 & 86.864 & 37.345 & 48.414 \\
\hline $5 \#$ & 35.09 & 69.482 & 114.321 & 59.832 & 72.855 \\
\hline $6 \#$ & 53.616 & 88.125 & 141.841 & 80.744 & 93.016 \\
\hline $7 \#$ & 25.619 & 50.469 & 91.041 & 44.177 & 54.949 \\
\hline $8 \#$ & 33.489 & 60.868 & 89.685 & 53.743 & 62.172 \\
\hline $9 \#$ & 43.269 & 73.304 & 118.167 & 65.162 & 77.486 \\
\hline \multicolumn{7}{|r}{} \\
\hline
\end{tabular}
(f) No. 6 nozzle

\begin{tabular}{|c|c|c|c|c|c|}
\hline $\begin{array}{c}\text { Nozzle } \\
\text { position }\end{array}$ & D10 & D50 & D90 & $\mathrm{D}[3,2]$ & $\mathrm{D}[4,3]$ \\
\hline $1 \#$ & 35.23 & 64.456 & 103.987 & 56.813 & 67.775 \\
\hline $2 \#$ & 49.704 & 95.949 & 149.58 & 82.234 & 97.892 \\
\hline $3 \#$ & 47.613 & 90.671 & 156.499 & 78.313 & 93.983 \\
\hline $4 \#$ & 39.867 & 64.037 & 100.559 & 59.182 & 67.774 \\
\hline $5 \#$ & 43.18 & 84.696 & 137.706 & 72.578 & 87.826 \\
\hline $6 \#$ & 48.884 & 92.618 & 149.471 & 80.429 & 95.96 \\
\hline $7 \#$ & 28.373 & 56.002 & 88.764 & 47.908 & 58.45 \\
\hline $8 \#$ & 34.095 & 68.253 & 129.471 & 59.221 & 75.094 \\
\hline $9 \#$ & 33.294 & 59.606 & 98.623 & 52.633 & 63.857 \\
\hline
\end{tabular}




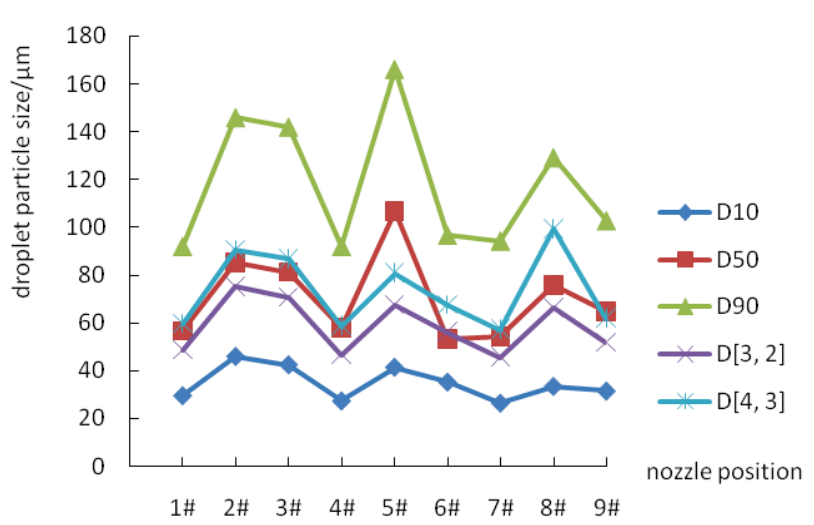

(a) No. 1 nozzle

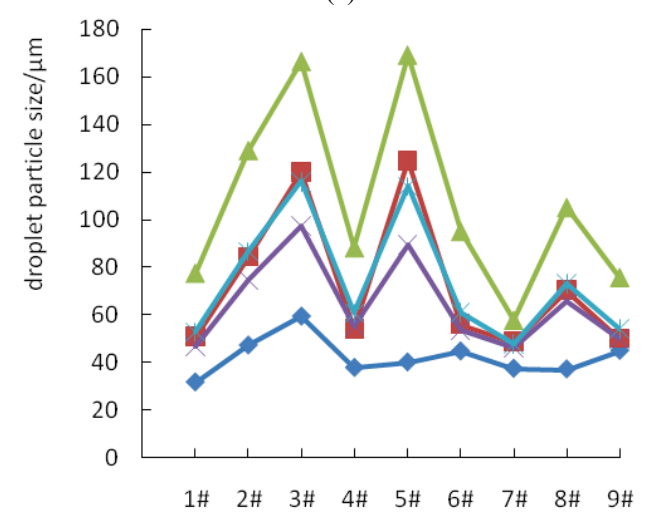

(b) No. 2 nozzle

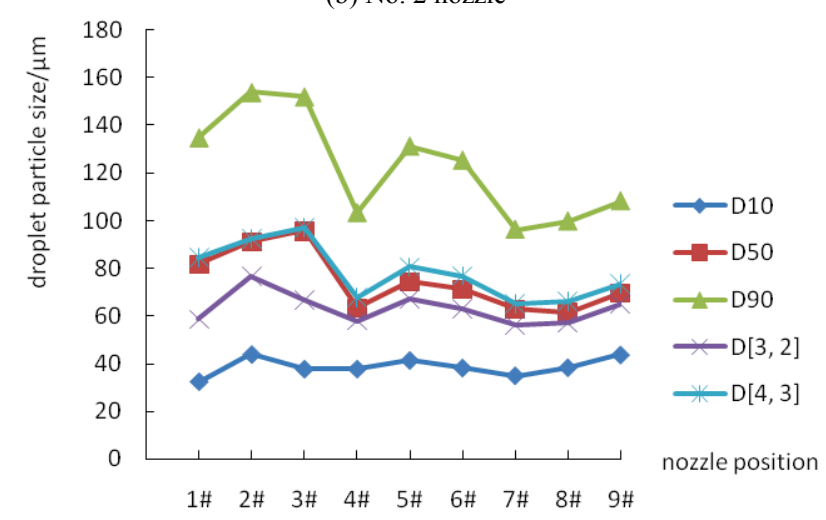

(c) No. 3 nozzle

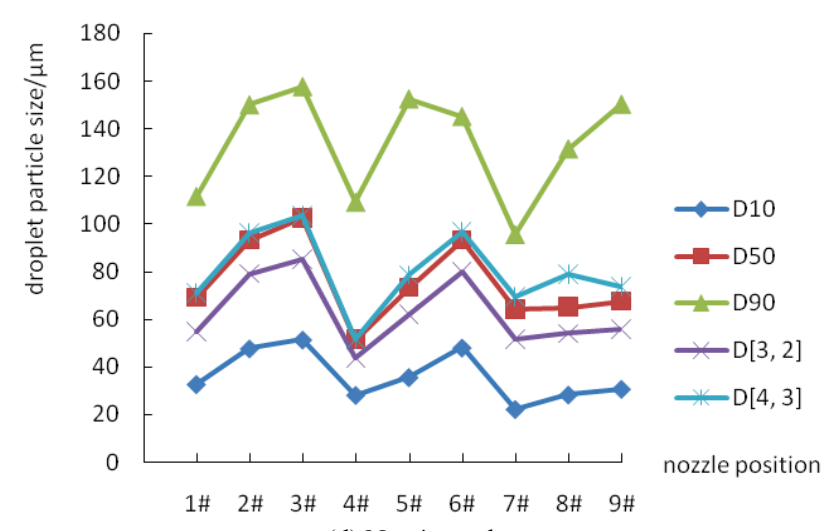

(d) No. 4 nozzle

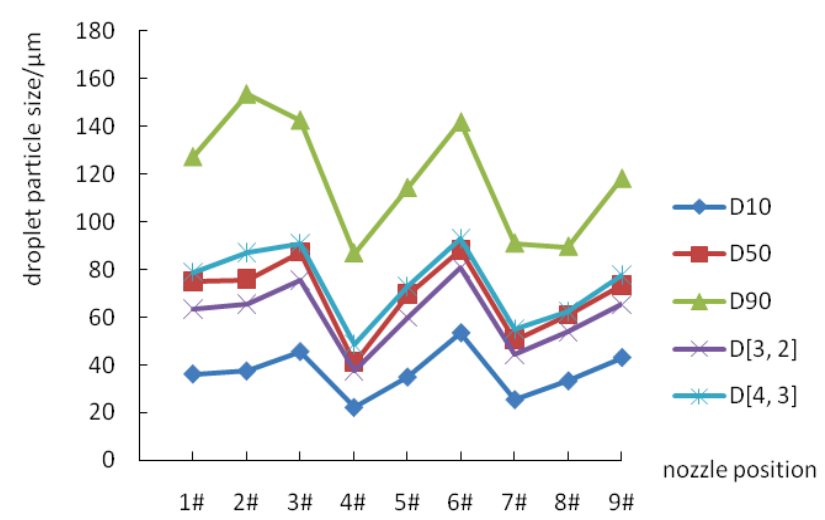

(e) No. 5 nozzle

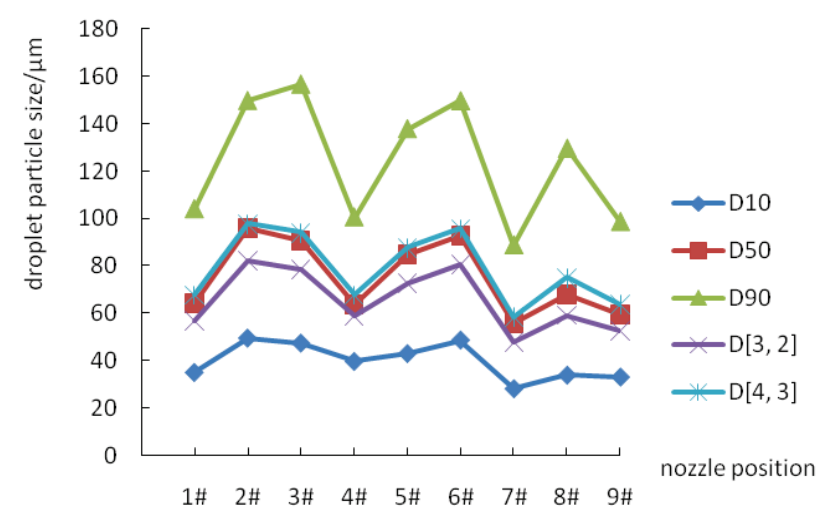

(f) No .6 nozzle

Figure 7 Particle sizes of droplets after starting fan

(2) While on the horizontal plane which was perpendicular to the mist flow's penetration, the change of particle size was contrary to that of without airflow, namely the farther away from the central axis of mist flow the droplet is, the larger its size will be, and vice versa.

(3) Due to the influence of airflow turbulence, compared with that before starting the fan, the droplets' particle sizes formed by each mechanical nozzle at different positions had much difference in values, while the overall change trend was that the airflow made the distribution range of droplets' particle sizes tend to be wider. For example, in view of the atomization field formed by No.2 nozzle, the value's range of D[4, 3], $\mathrm{D}[3,2], \mathrm{D} 90, \mathrm{D} 50$ and D10 varied from [55.089, 103.773] $\mu \mathrm{m}$ to $[47.835,116.033] \mu \mathrm{m},[49.207,88.335] \mu \mathrm{m}$ to $[46.235,97.354] \mu \mathrm{m},[75.897,164.280] \mu \mathrm{m}$ to $[57.700$, $168.949] \mu \mathrm{m},[53.318,100.78] \mu \mathrm{m}$ to $[48.512,124.670]$ $\mu \mathrm{m}$ and $[33.028,55.558] \mu \mathrm{m}$ to $[31.664,59.312] \mu \mathrm{m}$ respectively.

(4) Compared with that of without airflow, the droplets' particle sizes increased generally. For example, the average values of D10, D50, D90, D[3, 2] and D[4, 3] of droplets in atomization field formed by No.3 nozzle increased to $38.570 \mu \mathrm{m}, \quad 74.671 \mu \mathrm{m}, \quad 122.814 \mu \mathrm{m}$, $63.088 \mu \mathrm{m}, \quad 78.207 \mu \mathrm{m}$ from $29.285 \mu \mathrm{m}, 54.893 \mu \mathrm{m}$, $88.418 \mu \mathrm{m}, 47.759 \mu \mathrm{m}, 57.397 \mu \mathrm{m}$ respectively after starting the fan. The main reason for the above phenomenon was that the airflow turbulence increased the probability of mutual collision among droplets, making droplet's coalescence be the larger one more easily, which led to the overall trend of increasing size.

\section{Field Application}

The selection of mechanical nozzles used in shearer's external spray at \#10310 fully-mechanized caving workface of Xinglongzhuang coal mine of 
Yankuang Group in China was illustrated as an example. The parameters of D10, D50, D90, D[3, 2] and D[4, 3] of dust's particle size at shearer driver's position in \#10310 workface was $3.63 \mu \mathrm{m}, 6.54 \mu \mathrm{m}, 10.77 \mu \mathrm{m}, 5.32 \mu \mathrm{m}$, $7.98 \mu \mathrm{m}$ respectively. It was evident that the particle size of dust at driver's position was the finest, and the proportion of respirable dust was high, which threatened the miner's physical and mental health seriously.

It has been known that the atomized particle size decreases with the increasing in water pressure. Additionally, by analyzing the experimental result, it could be known that, influenced by the airflow's turbulence, the atomized particle size decreased with the decreasing in the distance between droplet and nozzle's orifice, while the droplet size increased with the increasing in the distance between droplet and the central axis of the mist field. Therefore, measures should be taken to optimize shearer's external spray system from the following three aspects: (1) Water pressure should be raised to $8.0 \mathrm{MPa}$ from $3.5 \mathrm{MPa}$. (2) The distance between external spray device and shearer's drum should be reduced from $2.3 \mathrm{~m}$ to $1.5 \mathrm{~m}$. (3) The central part of atomization field should be adjusted to the combinative section of the cutting head and the coal directly. In addition, in order to get a high capturing efficiency, the droplet size should be 10 times larger than the dust size $[21,22]$. On the basis of the atomization effect analysis of different mechanical nozzles with airflow, it could be known that the average values of D10, D50, D90, D[3, 2] and $\mathrm{D}[4,3]$ of droplets formed by No.1 nozzle under 8 $\mathrm{MPa}$ water pressure were $34.926 \mu \mathrm{m}, 70.622 \mu \mathrm{m}$, $117.669 \mu \mathrm{m}, 58.800 \mu \mathrm{m}$ and $73.612 \mu \mathrm{m}$ respectively. Namely the droplets' sizes formed by No.1 nozzle matched well with the particle sizes of dust at the shearer driver's position, meeting the field application requirements.

The field application effect of shearer's external spraying is shown in Fig. 8.

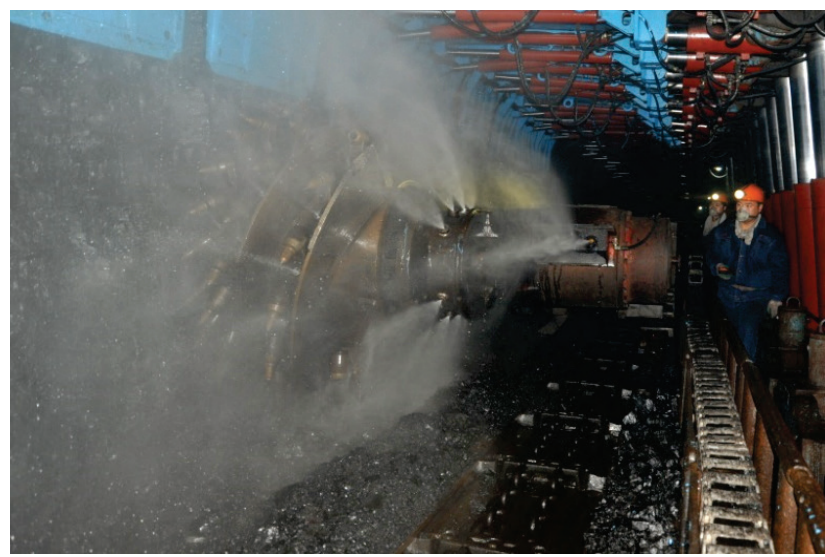

Figure 8 The physical map of shearer's external spraying

After spraying, the maximum concentration of whole and respirable dust at the shearer driver's position reduced to below $15 \mathrm{mg} / \mathrm{m}^{3}$ and $8 \mathrm{mg} / \mathrm{m}^{3}$ respectively, the dust reduction rate reached $92 \%$ and $90 \%$, achieving very good dedusting effect.

\section{$6 \quad$ Main conclusions}

(1) For the six different types of mechanical nozzles commonly used in coal mine, the quality order of atomization effects is: vortex centrifugal mixed type $>$ vortex centrifugal type (with gradually reduced body) $>$ vortex centrifugal type (without gradually reduced body) $>$ tangential centrifugal type $>$ Direct-spray type $>$ tangential centrifugal mixed type.

(2) When there's no airflow, in the zone of diffusion angle of atomization field, on the connection line between the centre of nozzle's orifice and any point in the effective jetting range, the closer to the nozzle the droplet is, the smaller its size will be, and vice versa. On the horizontal plane which was perpendicular to the mist flow's penetration, the closer to the central axis of mist flow the droplet is, the larger its size will be, and vice versa.

(3) Influenced by airflow disturbance, the average particle sizes of droplet group formed by different type of nozzles have an overall trend to increase. Moreover, the distribution range of droplets' particle sizes tend to be wider. However, the particle sizes near the central part of mist field tend to decrease.

(4) According to the dust's particle size at the position of shearer driver in \#10310 fully-mechanized caving workface of Xinglongzhuang coal mine, based on the results of spraying simulation experiment, vortex centrifugal (with gradually reduced body) stainless steel nozzles with atomization shape of full cone were selected as the external spraying nozzles for shearer, which achieved excellent dust reduction effects.

\section{Acknowledgements}

This work was financially supported by State Key Program of National Natural Science of China (Grant No. U1261205); National Natural Science Foundation of China (Grant No. 51474139, 51204103, 51404147); SDUST Research Fund (Grant No. 2014JQJH106); China Postdoctoral Science Foundation (2015M570602); Joint Innovative Center for Safe and Effective Mining Technology and Equipment of Coal Resources of Shandong Province; Open Fund of the State Key Laboratory of Mining Disaster Prevention and Control Co-founded by Shandong Province and the Ministry of Science and Technology (Grant No. MDPC2013KF13); Science and Technology Project of Huangdao District, Qingdao (Grant No. 2014-1-30); Open Fund of the Key Laboratory of Safety and High-efficiency Coal Mining, Ministry of Education (Anhui University of Science and Technology, Grant No. JYBSYS2014105); China Coal Industry Association Guidance Project of Scientific and Technological Research of the Year 2013 (Grant No. MTKJ2013-358); Science and Technology Development Program of Safety Production of Shandong Province (2014-110); The Key Technology Projects of Chinese State Administration of Work Safety for Preventing Major Safety Production Accidents (shandong-0083-2015AQ). 


\section{References}

[1] Nie, W.; Ma, X.; Cheng, W. M.; Zhou, G.; Xue, J.; Liu, Y. $\mathrm{H}$. Ventilation conditions' influences on the dust control air curtain at fully mechanized heading face. // Journal of China University of Mining \& Technology. 44, 4(2015), pp. 630-636. https://doi.org/10.13247/j.cnki.jcumt.000362

[2] Nie, W.; Cheng, W. M.; Zhou, G. Formation mechanism of pressure air curtain and analysis of dust suppression's effects in mechanized excavation face. // Journal of China Coal Society. 30, 3(2015), pp. 609-615. https://doi.org/10.13225/j.cnki.jccs.2014.0601

[3] Zhou, G.; Cheng, W. M.; Wang, G.; Chen, L. J. Optimal design of dust-settling device by water spraying for powered support in fully mechanized caving face annually producing 6 million tons of coal. // Journal of Shandong University of Science and Technology (Natural Science). 28, 4(2009), pp. 82-86.

[4] Cheng, W. M.; Liu, W.; Nie, W.; Zhou, G.; Cui, X. F.; Sun, $\mathrm{X}$. The prevention and control technology of dusts in heading and winning faces and its development tendency. // Journal of Shandong University of Science and Technology (Natural Science). 29, 4(2010), pp. 77-81.

[5] Xu, L. C.; Sun, H. P. Theory and application of fine mist capturing dust. // Industrial Safety and Dust Control. 4(1996), pp. 16-18.

[6] Dhariwal, V.; Hall, P. G.; Ray, A. K. Measurements of collection efficiency of single, charged droplets suspended in a stream of submicron particles with an electrodynamic balance. // Journal of Aerosol Science. 24, 2(1993), pp. 197-209. https://doi.org/10.1016/0021-8502(93)90058-H

[7] Hou, L. Y.; Hou, X. C. Nozzle Technical Manuals. China Petrochemical Press, Beijing, 2007.

[8] Faeth, G. M.; Hsiang, L. -P.; Wu, P. K. Structure and breakup properties of sprays. // International Journal of Multiphase Flow. 21, Supplement (1995), pp. 99-127. https://doi.org/10.1016/0301-9322(95)00059-7

[9] Ma, S. P.; Kou, Z. M. Study on mechanism of reducing dust by spray // Journal of China Coal Society. 30, 3(2005), pp. 297-300.

[10] Ma, S. P.; Kou, Z. M. Study and analysis of the efficiency on spray for suppressing airborne dust. // Journal of Taiyuan University of Technology. 37, 3(2006), pp. 327-330.

[11] Ma, S. P.; Kou, Z. M. Study on efficiency of dust suppression by mist spray and its matched parameters. // China Safety Science Journal. 16, 5(2006), pp. 84-88.

[12] Quan, Y. Y. Design of efficient fall dust nozzle in digging working face. // Coal Mine Machinery. 32, 2(2011), pp. 136-137. https://doi.org/10.13436/j.mkjx.2011.02.071

[13] Cheng, W. M.; Zhou, G.; Zuo, Q. M.; Nie, W.; Wang, G. Experimental research on the relationship between nozzle spray pressure and atomization particle size. // Journal of China Coal Society. 35, 8(2010), pp. 1308-1313. https://doi.org/10.13225/j.cnki.jccs.2010.08.027

[14] Zeng, Z. X.; Jiang, P.; Xie, W. M. Investigation of atomizer particle diameter. // Journal of Xi'an Jiaotong University. 34, 4(2000), pp. 75-77.

[15] Nie, W.; Cheng, W. M.; Zhou, G.; Xue, J.; Cui, X. F. Research and application on external spray secondary dust falling device with negative pressure of roadheader. // Journal of China Coal Society. 39, (12)2014, pp. 2446-2452. https://doi.org/10.13225/j.cnki.jccs.2013.1594

[16] Li, X. H.; Zhou, X. J.; Chen, H. A. Study on design of blow-spray dust catcher on tunneling faces. // Mining Machinery. 38, 17(2010), pp. 27-29.

[17] Gong, J. S.; Fu, W. Z. A putting forward of a new spray atomizer and the study of its flow characteristics. // Journal of Engineering Thermophysics. 26, 4(2005), pp. 507-510.

[18] Zhao, Y.; Cui, W. X. Design and application of high pressure spraying device for falling dust of heading machine. // Industry and Mine Automation. 40, 5(2014), pp. 88-90. https://doi.org/10.13272/j.issn.1671-251x.2014.05.022

[19] Zhou, G.; Cheng, W. M.; Chen, L. J.; Nie, W. Numerical simulation and its application of dust concentration spatial distribution regularities in fully-mechanized caving face. // Journal of China Coal Society. 35, 12(2010), pp. 2094-2099. https://doi.org/10.13225/..cnki.jccs.2010.12.026

[20] Zhou, G.; Cheng, W. M.; Chen, L. J. Research and Practice on the Key Theory and Technology of Coal Mine Dust Control. China Coal Industry Publishing House, Beijing, 2011.

[21] Zhou, G.; Cheng, W. M.; Wang, G.; Cui, X. F. Experiment research of the coupling relationship between dust field and droplet field about fully mechanized and roof caving workface. // Journal of China Coal Society. 35, 10(2010), pp. 1660-1664. https://doi.org/10.13225/j.cnki.jccs.2010.10.026

[22] Zhou, G.; Cheng, W. M.; Nie, W.; Wang, G. Extended theoretical analysis of jet and atomization under high-pressure spraying and collecting dust mechanism of droplet. // Journal of Chongqing University. 35, 3(2012), pp. 47-52.

\section{Authors' addresses}

Dr. Sc. Gang Zhou, Associate Professor

State Key Laboratory of Mining Disaster Prevention and Control Co-founded by Shandong Province and the Ministry of Science and Technology

Shandong University of Science and Technology Qianwangang Road 579, 266590 Qingdao, China

College of Mining and Safety Engineering Shandong University of Science and Technology Qianwangang Road 579, 266590 Qingdao, China

Key Laboratory of Safety and High-efficiency Coal Mining of Ministry of Education

Anhui University of Science and Technology Shungeng Middle Road 168, 232001 Huainan, China

E-mail: zhougang@sdust.edu.cn

\section{B.E. Mao XU, M. Sc. Student}

College of Mining and Safety Engineering Shandong University of Science and Technology Qianwangang Road 579, 266590 Qingdao, China

\section{B.E. Han Oiu, M. Sc. Student}

College of Mining and Safety Engineering Shandong University of Science and Technology Qianwangang Road 579, 266590 Qingdao, China

\section{Dr. Sc. Wen Nie, Lecturer, corresponding author} College of Mining and Safety Engineering Shandong University of Science and Technology Qianwangang Road 579, 266590 Qingdao, China $+8653286058080$

E-mail: skdniewen@163.com

\section{Dr. Sc. Weimin Cheng, Professor}

State Key Laboratory of Mining Disaster Prevention and Control Co-founded by Shandong Province and the Ministry of Science and Technology

Shandong University of Science and Technology Qianwangang Road 579, 266590 Qingdao, China

\section{B.E. Cong Chen, M. Sc. Student}

College of Mining and Safety Engineering

Shandong University of Science and Technology Qianwangang Road 579, 266590 Qingdao, China 